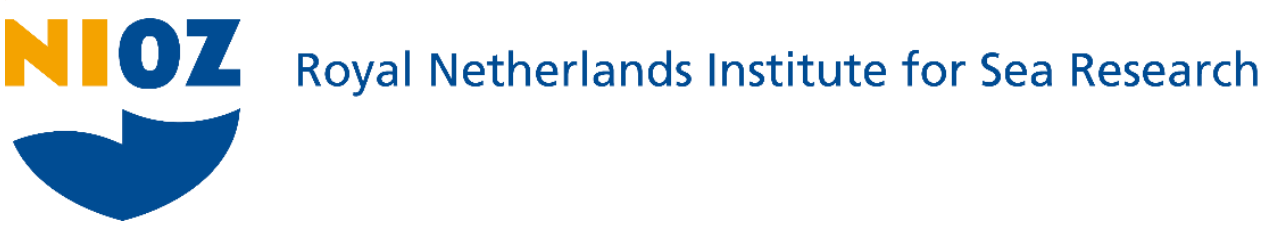

This is a pre-copyedited, author-produced version of an article accepted for publication, following peer review.

Luttikhuizen, P.C.; Beermann, J.; Crooijmans, R.P.M.A.; Jak, R.G. \& Coolen, J.W.P. (2019). Low genetic connectivity in a fouling amphipod among man-made structures in the southern North Sea. Marine Ecology Progress Series, 615, 133-142

Published version: https://dx.doi.org/10.3354/meps12929

Link NIOZ Repository: http://www.vliz.be/imis?module=ref\&refid=310708

[Article begins on next page]

The NIOZ Repository gives free access to the digital collection of the work of the Royal Netherlands Institute for Sea Research. This archive is managed according to the principles of the Open Access Movement, and the Open Archive Initiative. Each publication should be cited to its original source - please use the reference as presented.

When using parts of, or whole publications in your own work, permission from the author(s) or copyright holder(s) is always needed. 


\section{Low genetic connectivity in a fouling amphipod among man-made structures}

\section{2 in the southern North Sea}

3 Pieternella C. Luttikhuizen ${ }^{1 *}$, Jan Beermann ${ }^{2,3}$, Richard P.M.A. Crooijmans ${ }^{4}$, Robbert G. Jak ${ }^{5}$, Joop W.P.

4 Coolen ${ }^{5,6}$

$5 \quad{ }^{1}$ NIOZ Royal Netherlands Institute for Sea Research, Department of Coastal Systems, and Utrecht

6 University, P.O. Box 59, 1790AB Den Burg, The Netherlands

${ }^{2}$ Alfred Wegener Institute Helmholtz Centre for Polar and Marine Research, Department of Functional

Ecology, Am Handelshafen 12, 27570 Bremerhaven, Germany

${ }^{3}$ Helmholtz Institute for Functional Marine Biodiversity, Ammerländer Heerstraße 231, 26129,

Oldenburg, Germany

${ }^{4}$ Wageningen University \& Research, Animal Breeding and Genomics, Droevendaalsesteeg 1, 6708 PB Wageningen, The Netherlands

${ }^{5}$ Wageningen Marine Research, P.O. Box 57, 1780 AB Den Helder, The Netherlands

${ }^{6}$ Wageningen University, Chair group Aquatic Ecology and Water Quality Management, Droevendaalsesteeg 3a, 6708 PD Wageningen, The Netherlands

\section{*Corresponding author: e-mail: pieternella.luttikhuizen@nioz.nl}

Running page head: Low connectivity among man-made structures

Keywords: genetic structure, connectivity, offshore oil platforms, offshore wind farm, amphipod, biofouling, gene flow.

Abstract: Offshore environments are increasingly invaded by man-made structures that form hardsubstrate habitats for many marine species. Examples include oil and gas platforms, wind turbines and ship wrecks. One of the hypothesised effects is an increased genetic connectivity among natural populations due to new populations growing on man-made structures that may act as steppingstones. However, very little data is available on genetic connectivity among artificial offshore structures. Here, we present study on the common fouling amphipod Jassa herdmani from offshore 
structures in the southern North Sea. Partial mitochondrial DNA sequences (cytochrome-c-oxidase 1, $N=514$ ) were obtained from 17 locations in the southern North Sea, all artificial structures: 13 ship wrecks, two wind turbines and two platforms. Samples from these locations were found to be significantly differentiated, meaning that strong population structure exists for this species in the area. Levels of intraspecific variation were consistent with stable population sizes. No evidence was found for isolation-by-distance. Using coalescent simulations, the oldest population subdivision events were estimated to date back to the time the study area was flooded following the Last Glacial Maximum. We therefore tentatively conclude that J. herdmani may have colonised man-made structures from previously existing populations on the sea floor, and that the increase in offshore installations has not led to an overall increase in genetic connectivity for this species. 


\section{INTRODUCTION}

Offshore man-made hard structures such as the submerged parts of oil and gas platforms and offshore wind turbines, but also navigational buoys and ship wrecks, form suitable but artificial habitat for biological hard-substrate communities (Firth et al. 2016, Bishop et al. 2017). The offshore environment is in this way a growing extension of naturally occurring hard bottom substrates. Very little is known to date about the extent to which species are able to disperse among these offshore structures (i.e., their connectivity) (but see Mauro et al. 2001, Atchison et al. 2008, Fauvelot et al. 2009, 2012, Sammarco et al. 2012, 2017). However, this is important knowledge for protection and management of offshore ecosystems as well as for decision-making concerning the offshore structures themselves (Duarte et al. 2013, Adams et al. 2014). The structures may function as stepping stones for dispersal of species that are otherwise unable to reach particular locations by lack of intermediate settlement opportunities (Adams et al. 2014). This may facilitate the spread of non-indigenous species as well as indigenous ones or species of conservation value (Gass \& Roberts 2006, De Mesel et al. 2015).

The small tube-dwelling amphipod crustacean Jassa herdmani (Walker, 1893) is a common and native component of fouling communities on artificial structures in the southern North Sea together with its congener J. marmorata Holmes, 1905 (De Mesel et al. 2015). Jassa herdmani occurs mainly on ship wrecks and on the deeper parts of vertical structures, such as the foundations of wind turbines and platforms, where the species can reach remarkably high abundances of more than a million individuals per $\mathrm{m}^{2}$ (e.g., Zintzen et al. 2008a, Krone et al. 2013, Coolen et al. 2018). Surprisingly, although J. herdmani has been reported to co-occur with J. marmorata and J. falcata (Montagu, 1808) in the inner German Bight, it was not found on the natural rock substrates in areas such as the Borkum reef grounds (near ST0729 in Figure 1) (Beermann 2014, Coolen et al. 2015). 
Most amphipods in temperate seas exhibit high fecundities with multiple broods per year allowing for high secondary production (Sheader \& Chia 1970, Sheader 1981, Highsmith \& Coyle 1991). Furthermore, short generation times and a holobenthic life cycle due to the direct development of amphipod embryos facilitate successful colonisation and rapid production of dense populations in Jassa species (Beermann \& Purz 2013, Beermann 2014). Jassa populations are characterized by a marked short-distance dispersal of juveniles (Franz \& Mohamed 1989). However, older juveniles and adults can exhibit long-distance dispersal under certain conditions, drifting with the water surface layer and may colonize new substrates in that way (Havermans et al. 2007). In the southern North Sea, the hard-substrate habitats are predominantly restricted to anthropogenic constructions such as shipwrecks, foundations of wind turbines and oil and gas platforms, and buoy moorings. These suitable substrates for Jassa are surrounded by soft sediments and J. herdmani populations are consequently characterized by patchy distributions.

Population structure and genetic connectivity have thus far not been studied for Jassa herdmani. The closely related J. marmorata was studied for two allozyme loci at two nearby (approx. $8 \mathrm{~km}$ apart) on-shore locations, which were found not to be differentiated (McDonald 1991). Two amphipods Gammarus spp., whose life cycle and ecology resemble that of Jassa spp., were found to show population structure, and reduced levels of genetic diversity consistent with postglacial demographic expansion (Krebes et al. 2011). In partial contrast to its known ability to be an effective colonizer, we hypothesise that connectivity between local J. herdmani populations is limited to adjacent platforms or nearby natural habitats and that we will find a signal of isolation-by-distance. The southern North Sea region was formed and recolonized relatively recently, after the Last Glacial Maximum. We therefore expect to find signatures of population subdivision dating from after that time.

The aim of the current project was to examine whether a common species of offshore fouling communities displays signatures of genetic connectivity among offshore man-made structures. For 
this purpose, we analysed DNA sequences from J. herdmani specimens sampled at ship wrecks, wind turbines and oil and gas platforms in the southern North Sea.

\section{METHODS}

\subsection{Sample collection}

Samples were collected in 2015 and 2016 at 22 locations by divers and during maintenance activities on wind turbine foundations, jackets of oil and gas platforms, navigational buoys, and shipwrecks in the southern North Sea (Table 1). Sample depth ranged from 0 to 46 meters overall, while within a location it varied between 0 and $5 \mathrm{~m}$ away from the depth reported in Table 1. Samples were collected opportunistically, from an area of several $\mathrm{m}^{2}$ on shipwrecks, to samples of $100 \mathrm{~cm}^{2}$ on some installations and from dive suits after resurfacing of divers. After collection samples were either stored on $95 \%$ ethanol or frozen directly at $-20^{\circ} \mathrm{C}$. Frozen samples were stored at $-80^{\circ} \mathrm{C}$ after transportation to the laboratory. Jassa herdmani occurs alongside J. marmorata in the study area, and the species were separated based on their DNA sequence (see below).

\subsection{Molecular procedures}

DNA was isolated from entire Jassa spp. individuals using the Qiagen Tissue kit following the manufacturer's protocol. DNA concentrations were quantified by using the Tecan Freedom Evo and qualified on $1 \%$ agarose gels. DNA was diluted to $5 \mathrm{ng} / \mu \mathrm{l}$ and amplified with primers jgLCO-M13F (PCR) 16-001 (5'-TGTAAAACGACGGCCAGTTITCIACIAAYCAYAARGAYATTGG-3') and jgHCO-M13R (PCR) 16-002 ('5-CAGGAAACAGCTATGACTAIACYTCIGGRTGICCRAARAAYCA-3’). PCR reaction was performed in $12 \mu \mathrm{l}$ using One TAQ solution containing $0.1 \mathrm{ng} / \mu \mathrm{l} \mathrm{BSA}$. Initial denaturation was done at $94^{\circ} \mathrm{C}$ for 5 min, followed by 50 cycles of denaturation at $94{ }^{\circ} \mathrm{C}$ for $45 \mathrm{~s}$, annealing at $43^{\circ} \mathrm{C}$ for $45 \mathrm{~s}$ and extension at $72^{\circ} \mathrm{C}$ for $80 \mathrm{~s}$, with a final elongation step of $72^{\circ} \mathrm{C}$ for 7 min. PCR products were checked on $1 \%$ agarose gels before purification using Millipore Multiscreen plates. Purified PCR product was sequenced using the M13 Forward primer M13F ('5-TGTAAAACGACGGCCAGT-3’) and Big Dye v3.1. 
Sequencing reaction products were purified by precipitation with Na Ac-EDTA and $100 \%$ ethanol and dissolved in 10 ul formamide and analysed on a 48 capillary $A B I$ fragment analyser. Sequences were analysed using the Staden package (Staden et al. 2000).

\subsection{Data analyses}

Sequences were aligned manually in BioEdit (Hall 1999). Jassa marmorata sequences were identified by comparing to available Genbank sequences; this could be done unequivocally because the $\mathrm{COI}$ sequence difference between J. herdmani and J. marmorata is approximately $20 \%$ (Raupach et al. 2015). Haplotypes and haplotype frequencies for J. herdmani per sample were extracted from the alignment using custom Python script (Luttikhuizen 2019). Amino acid translation of codons was examined using MEGA v. 7.0.21 (Kumar et al. 2016). All population genetic analyses were carried out in Arlequin v. 3.5 (Excoffier \& Lischer 2010). Population structure was analysed using one-way Analysis of Molecular Variance (AMOVA) and pairwise levels of population differentiation among all sample pairs was estimated as pairwise $\Phi_{\text {ST. }}$. Significance levels of $\Phi_{S T}$ values were evaluated on the basis of 10,000 random permutations of the data and Bonferroni correction for multiple testing. Hierarchical AMOVAs were constructed to test for genetic differentiation between wrecks versus platforms and turbines, and for year of sampling (2015 versus 2016). A minimum spanning network among haplotypes was estimated using pairwise numbers of nucleotide differences as genetic distance measure. Tajima's D (Tajima 1989) and Fu's $F_{s}$ (Fu 1996) were estimated to test for recent population expansion (using 10,000 permutations).

To test for isolation by distance, pairwise $\Phi_{\text {ST }}$ values were compared with linear distances between sampling stations. The latter were calculated using the package 'Fossil' version 0.3.7 in R version 3.4.3 (R Core Team 2018). Correlation between the $\Phi_{\text {Sт }}$ matrix and the linear distances matrix was evaluated with a Mantel test and 10,000 permutations in R. To visualise heterogeneity among samples a multidimensional scaling plot (MDS) was made in R. 
142 Divergence time estimates were made by simulating population subdivision following a coalescent

143 isolation-with-migration approach (Hey \& Nielsen 2007, Sethuraman \& Hey 2016). As a molecular

144 clock we used $2.35 \%$ sequence divergence per million years, as estimated for COI across a range of

145 crustacean species (see Krebes et al. 2011 and references therein). Molecular clock estimates for

146 crustaceans vary from $1.4 \%$ to $3.1 \%$ and are not different from molecular clock estimates for the

147 broader taxonomic group of the arthropods, which are, e.g., $2.0 \%$ for beetles (Juan et al. 1995) and

$148 \quad 2.3 \%$ for butterflies (Brower 1994). Taking into account that J. herdmani has a shorter generation

149 time than the typical one year for crustaceans, and assuming it to be three times as short, we arrived

150 at a mutation rate per year per 658 bp locus of $2.32 \cdot 10^{-5}$ following the approach by Papadopoulos et

151 al., (2005) and Luttikhuizen et al., (2008). Coalescent simulations were run using the IMa2 MCMC

152 implementation with the HKY mutation model to account for heterogeneity among sites, which is

153 crucial for mitochondrial data (Hasegawa et al. 1985), 10 heated chains with geometric heating, five

154 million burnin steps and saving 100,000 genealogies interspaced with 100 steps.

155

Population divergence times were estimated for a set of three sample pairs that had among the highest pairwise $\Phi_{\text {ST }}$ values in order to gauge what the oldest splitting times among our studied locations may have been. These pairs were: SW059-SW0933 $\left(\Phi_{\mathrm{ST}}=0.411\right), \mathrm{SP} 1033-\mathrm{SW} 0932\left(\Phi_{\mathrm{ST}}=\right.$

\section{RESULTS}

A total of 529 partial COI sequences were obtained from 22 locations and cropped to a length of 658 base pairs (Table 1). Among these, 44 different haplotypes were detected (Genbank accession numbers MH052599-MH052642). Five samples with less than 15 individuals sequenced were omitted from the analyses, leaving 42 haplotypes among 514 sequenced individuals in the final data set 
shows their spatial distribution in the study area. The colours of haplotypes in Figure 1 corresponds to those in Figure 2.

The 42 haplotypes totalled 27 variable sites. All except one of the substitutions were synonymous, and the non-synonymy of the only exception is questionable as it concerns a change from AGG to GGG in haplotypes 35 (one individual at location ST0729) and 38 (one individual at location SW0935), which may have a different translation in some Arthropoda than in the standard invertebrate mitochondrial code (Abascal et al. 2006). Because of this, and because none of the mutations translated to a frame shift and sequence length was as expected, we can conclude that we did not sequence any pseudogenes.

Analysis of molecular variance (AMOVA) showed that genetic variation was significantly differentiated among sampling locations, with an overall $\Phi_{\text {ST }}$ of $0.159(p<0.00001)$ (Table 2). Pairwise $\Phi_{S T}$ 's were significantly larger than zero in 84 of the total of 136 comparisons (Bonferroni corrected $p_{\text {adj }}=0.00037 ;$ Table 3). A two-level AMOVA with two groups as upper level (shipwrecks versus platforms and turbines, which coincides with a north-south split) showed that there is a significant difference associated with this upper level $\left(\Phi_{C T}=0.0613, p=0.0144\right)$ as well as among samples within these groups $\left(\Phi_{s c}=0.137, p<0.00001\right)$. A second two-level AMOVA with sampling year (2015 versus 2016) as upper level similarly also shows a significant difference at this upper level $\left(\Phi_{C T}=0.0398, p=0.0315\right)$ and again also among samples within years $\left(\Phi_{S C}=0.144, p<0.00001\right)$.

Figure 3 is a multidimensional scaling plot (MDS) for the Jassa herdmani COI sequences among the 17 sampling locations depicting the variation associated with sampling year, latitude and substrate type.

None of the Tajima's D or Fu's $F_{s}$ values differed significantly from zero, which is consistent with stable population sizes (Table 1). Linear distance between sampling locations did not correlate with 
pairwise $\Phi_{\text {ST }}$ values based on a Mantel test (Mantel $r=-0.00315$, n.s.), meaning that no evidence for an isolation-by-distance effect was seen in the data (Figure 4).

Divergence time estimates based on coalescent simulations for three of the most strongly differentiated sample pairs ranged from 3,578 to 11,080 years ago (Table 4). Simultaneously estimated migration rates were very low and ranged from 0.060 to 0.61 (Table 4).

\section{DISCUSSION}

Our results show that offshore populations on man-made structures of the common fouling amphipod Jassa herdmani are strongly genetically differentiated in the southern North Sea with an overall $\Phi_{\text {ST }}$ of 0.156 (Table 3 and Table 2A). Our first hypothesis that gene flow among populations of J. herdmani is limited is thus corroborated, but the second one of isolation-by-distance is not. Supporting the third hypothesis, the observed population structure was indeed estimated to have been formed after the last glacial maximum. Man-made structures therefore do not appear to facilitate genetic connectivity for this species in the southern North Sea area.

Hierarchical analyses of molecular variance (AMOVA) indicated that most of the population structure is found at the among-sample level (Table 2). In addition, small but significant levels of population structure could be be attributed to a north-south difference (Table 2A, Figure 3), a difference of shipwrecks versus platforms and turbines (Table 2B, Figure 3), and to the two sampling years (Table 2C, Figure 3). As this study was not designed to test for any of these factors (north-south, type of habitat, sampling year) we also cannot discriminate among them post-hoc. This can be seen in Figure 3: e.g., in 2015 more northerly samples were taken than in 2016, and more shipwrecks were sampled at lower latitudes. If there was a genetic north-south subdivision, this should have been reflected in an isolation-by-distance, which was not observed (Figure 4). We conclude that there is no clear substructure for the study species in this region but instead most likely a mosaic pattern. Future 
research should employ a more rigorous sampling design that includes a north-south gradient for several types of habitats, repeated in different years, in order to discriminate among these factors.

Some of the deepest differentiation detected was estimated to trace back in time to the period soon after the Last Glacial Maximum (LGM) (Table 4). The dates of population subdivision should be interpreted with caution, because they are based on data for a single, maternally inherited genetic locus only. Future work should include data from additional independent, preferably nuclear, loci. Further uncertainty stems from the application of a molecular clock to mitochondrial DNA and the assumptions made when using such a clock (Ballard \& Whitlock 2004). The southern North Sea area was dry land during the LGM, called Doggerland (Coles 2000), connecting the British Isles with mainland Europe. Doggerland was flooded gradually and the land connection disappeared around 8000 years ago (Eisma et al. 2009). The dates obtained here for population subdivision in J. herdmani are remarkably consistent with that time: the oldest splits between populations are estimated to have happened 3.5 to 11 thousand years ago (Table 4). An alternative possibility for the observed population structure is the direct development of J. herdmani in combination with its high fecundity, which may lead to rapid local population turnover (Beermann \& Purz 2013). The observed mosaic differences among our samples would then reflect a more recently originated structure. We deem the latter unlikely, because, while dating events using molecular clock estimates for a single gene comes with many uncertainties (Wilke et al. 2009), COI clock estimates are actually rather similar across different crustacean and even arthropod species (Brower 1994, Juan et al. 1995, Krebes et al. 2011). However, rapid local population turnover may have contributed to population divergence by essentially decreasing effective population size. We therefore tentatively conclude that at least part of the geologically recent population structure among populations of J. herdmani in the southern North Sea dates back to the time when the region was colonized by this species for the first time, i.e. following the flooding of Doggerland. Jassa herdmani is not able to survive on soft bottoms, which today comprises the majority of the North Sea seafloor. The present-day distribution of J. herdmani 
in the North Sea is still fragmentarily known, partly due to the former taxonomic confusion within the genus (Conlan 1990), but confirmed locations include the coasts of Britain, Norway, Denmark, Germany, the Netherlands and Belgium (see Beermann and Franke, 2011 and references therein). The species may have lived on bolder fields and flat oyster beds (Sas et al. 2018) and it has probably lived on ship wrecks ever since they were around (Zintzen et al. 2006, 2008b). The scarcity of natural hard bottoms may also have contributed to genetic differentiation of J. herdmani populations growing on natural (mostly coastal) hard substrates before the anthropogenic transformation with artificial hard substrates.

The observation that the populations have probably been stable in size at all sampled locations (Table 1) provides further support for the idea that Jassa herdmani populations have survived in the southern North Sea ever since the habitat was formed. At an average temperature of $15^{\circ} \mathrm{C}$, reproductively active females of $J$. herdmani should survive more than 3-4 months (predation excluded), producing broods of up to 100 juveniles every 20 days and all year round (Beermann \& Purz 2013, Beermann 2014). Thus, the generation time of J. herdmani is relatively short. As a result, individuals from the sampled locations may have originated from only few colonizing individuals that built dense populations in a short time; in fact, even a single brooding female would have sufficed. However, the non-significant Tajima's D and Fu's $F_{s}$ 's (Table 1) and the large haplotypic diversity suggest that population sizes during such potential bottlenecks tend to be at least large enough to maintain most of the genetic variation.

The absence of pelagic larvae in this species' life cycle is consistent with our inference of low connectivity, and the dispersal potential for older J. herdmani (Havermans et al. 2007) apparently does not lead to an important amount of realised dispersal. The latter is the case not only for the present day but also for the longer, evolutionary time scale of several thousands of years - which means several tens of thousands of generations for J. herdmani. 
271 In conclusion, this study adds to the few available studies on genetic connectivity among offshore

272 man-made structures. The data presented here for the amphipod Jassa herdmani in the southern

273 North Sea show that genetic connectivity among such structures is small. Future studies should focus on obtaining genetic data for more loci and on smaller spatial scales in order to identify the scale of genetic mixing.

\section{Data accessibility}

Table S1. Haplotype frequencies for 658 base pair cytochrome c oxidase I sequences for $\mathrm{N}=514$ Jassa herdmani individuals at 17 locations in the southern North Sea.

\section{Acknowledgements}

Neptune Energy (previously ENGIE Exploration \& Production Nederland B.V.) allowed and facilitated us to sample their installations and we are especially grateful to Ed Schmidt, Nathalie Kaarls, UIf Sjöqvist, Maico Vrijenhoeff, Ben Waardenburg and Kees van Braak for their help arranging this cooperation.

Much help in the field, e.g., collecting samples, allowing us access or performing analyses was provided by many individuals and organisations, including the crew of the vessels Seamar Splendid and Cdt. Fourcault, the Bluestream dive team, the Dive the North Sea Clean foundation and its many volunteers, Roland Krone from Krone Projekte, and Bert Dibbits at Wageningen University \&

292 This work was supported by the Wageningen UR TripleP@Sea Innovation program [grant number KB293 14-007]; NWO Domain Applied and Engineering Sciences [grant number 14494]; the Nederlandse 294 Aardolie Maatschappij BV, Wintershall Holding GmbH, Energiebeheer Nederland B.V. and the oil and gas joint industry INSITE fund, through the RECON project. 


\section{Literature cited}

Abascal F, Posada D, Knight RD, Zardoya R (2006) Parallel evolution of the genetic code in arthropod mitochondrial genomes (D Hillis, Ed.). PLoS Biol 4:711-718

Adams TP, Miller RG, Aleynik D, Burrows MT (2014) Offshore marine renewable energy devices as stepping stones across biogeographical boundaries (M Frederiksen, Ed.). J Appl Ecol 51:330-338

Atchison AD, Sammarco PW, Brazeau DA (2008) Genetic connectivity in corals on the Flower Garden Banks and surrounding oil/gas platforms, Gulf of Mexico. J Exp Mar Bio Ecol 365:1-12

Ballard JWO, Whitlock MC (2004) The incomplete natural history of mitochondria. Mol Ecol 13:729744

Beermann J (2014) Spatial and seasonal population dynamics of sympatric Jassa species (Crustacea, Amphipoda). J Exp Mar Bio Ecol 459:8-16

Beermann J, Franke H-D (2011) A supplement to the amphipod (Crustacea) species inventory of Helgoland (German Bight, North Sea): indication of rapid recent change. Mar Biodivers Rec 4:e41

Beermann J, Purz AK (2013) Comparison of life history parameters in coexisting species of the genus Jassa (Amphipoda, Ischyroceridae). J Crustac Biol 33:784-792

Bishop MJ, Mayer-Pinto M, Airoldi L, Firth LB, Morris RL, Loke LHL, Hawkins SJ, Naylor LA, Coleman RA, Chee SY, Dafforn KA (2017) Effects of ocean sprawl on ecological connectivity: impacts and solutions. J Exp Mar Bio Ecol 492:7-30

Brower A V (1994) Rapid morphological radiation and convergence among races of the butterfly Heliconius erato inferred from patterns of mitochondrial DNA evolution. Proc Natl Acad Sci U S A 91:6491-6495

Coles BJ (2000) Doggerland: the cultural dynamics of a shifting coastline. Geol Soc London, Spec Publ $175: 393-401$

Conlan KE (1990) Revision of the crustacean amphipod genus Jassa Leach (Corophioidea: Ischyroceridae). Can J Zool 68:2031-2075 
Coolen JWP, Bos OG, Glorius S, Lengkeek W, Cuperus J, Weide B van der, Agüera A (2015) Reefs, sand and reef-like sand: A comparison of the benthic biodiversity of habitats in the Dutch Borkum Reef Grounds. J Sea Res 103:84-92

Coolen JWP, Weide B van der, Cuperus J, Blomberg M, Moorsel GWNM Van, Faasse MA, Bos OG, Degraer S, Lindeboom HJ (2018) Benthic biodiversity on old platforms, young wind farms, and rocky reefs. ICES J Mar Sci 2018

Duarte CM, Pitt KA, Lucas CH, Purcell JE, Uye S, Robinson K, Brotz L, Decker MB, Sutherland KR, Malej A, Madin L, Mianzan H, Gili J-M, Fuentes V, Atienza D, Pagés F, Breitburg D, Malek J, Graham WM, Condon RH (2013) Is global ocean sprawl a cause of jellyfish blooms? Front Ecol Environ 11:91-97

Eisma D, Mook WG, Laban C (2009) An early Holocene tidal flat in the Southern Bight. In: Holocene marine sedimentation in the North Sea basin. Blackwell Publishing Ltd., Oxford, UK, p 229-237

Excoffier L, Lischer HEL (2010) Arlequin suite ver 3.5: a new series of programs to perform population genetics analyses under Linux and Windows. Mol Ecol Resour 10:564-567

Fauvelot C, Bertozzi F, Costantini F, Airoldi L, Abbiati M (2009) Lower genetic diversity in the limpet Patella caerulea on urban coastal structures compared to natural rocky habitats. Mar Biol $156: 2313-2323$

Fauvelot C, Costantini F, Virgilio M, Abbiati M (2012) Do artificial structures alter marine invertebrate genetic makeup? Mar Biol 159:2797-2807

Firth LB, Knights AM, Bridger D, Evans AJ, Mieszkowska N, Moore P, O'Connor NE, Sheehan E, Thompson RC, Hawkins SJ (2016) Ocean sprawl: Challenges and opportunities for biodiversity management in a changing world. Oceanogr Mar Biol An Annu Rev 54:189-262

Franz DR, Mohamed Y (1989) Short-distance dispersal in a fouling community amphipod crustacean, Jassa marmorata Holmes. J Exp Mar Bio Ecol 133:1-13

Fu YX (1996) Statistical tests of neutrality against population growth, hitchiking and background selection. Genetics 147:915-925 
Gass SE, Roberts JM (2006) The occurrence of the cold-water coral Lophelia pertusa (Scleractinia) on oil and gas platforms in the North Sea: Colony growth, recruitment and environmental controls on distribution. Mar Pollut Bull 52:549-559

Hall TA (1999) BioEdit: a user-friendly biological sequence alignment editor and analysis program for Windows 95/98/NT. Nucleic Acids Symp Ser 41:95-98

Hasegawa M, Kishino H, Yano T aki (1985) Dating of the human-ape splitting by a molecular clock of mitochondrial DNA. J Mol Evol 22:160-174

Havermans C, Broyer C De, Mallefet J, Zintzen V (2007) Dispersal mechanisms in amphipods: a case study of Jassa herdmani (Crustacea, Amphipoda) in the North Sea. Mar Biol 153:83-89

Hey J, Nielsen R (2007) Integration within the Felsenstein equation for improved Markov chain Monte Carlo methods in population genetics. Proc Natl Acad Sci U S A 104:2785-2790

Highsmith RC, Coyle KO (1991) Amphipod life histories: Community structure, impact of temperature on decoupled growth and maturation rates, productivity, and P:B ratios. Integr Comp Biol $31: 861-873$

Juan C, Oromi P, Hewitt GM (1995) Mitochondrial DNA phylogeny and sequential colonization of Canary Islands by darkling beetles of the genus Pimelia (Tenebrionidae). Proc R Soc B Biol Sci 261:173-180

Krebes L, Blank M, Bastrop R (2011) Phylogeography, historical demography and postglacial colonization routes of two amphi-atlantic distributed amphipods. Syst Biodivers 9:259-273

Krone R, Gutow L, Joschko TJ, Schröder A (2013) Epifauna dynamics at an offshore foundation Implications of future wind power farming in the North Sea. Mar Environ Res 85:1-12

Kumar S, Stecher G, Tamura K (2016) MEGA7: Molecular Evolutionary Genetics Analysis Version 7.0 for bigger datasets. Mol Biol Evol 33:1870-1874

Luttikhuizen PC (2019) COLLARL. Python script to extract haplotypes from an intraspecific DNA alignment and to produce an Arlequin infile. Https://github.com/pluttik/collarl.

Luttikhuizen PC, Campos J, Bleijswijk J van, Peijnenburg KTCA, Veer HW van der (2008) 
Phylogeography of the common shrimp, Crangon crangon (L.) across its distribution range. Mol Phylogenet Evol 46:1015-1030

Mauro A, Parrinello N, Arculeo M (2001) Artificial environmental conditions can affect allozyme genetic structure of the marine gastropod Patella caerulea. J Shellfish Res 20:1059-1063

McDonald JH (1991) Contrasting amounts of geographical variation as evidence for direct selection: The mpi and pgm loci in eight crustacean species. Heredity (Edinb) 67:215-219

Mesel I De, Kerckhof F, Norro A, Rumes B, Degraer S (2015) Succession and seasonal dynamics of the epifauna community on offshore wind farm foundations and their role as stepping stones for non-indigenous species. Hydrobiologia 756:37-50

Papadopoulos LN, Peijnenburg KTCA, Luttikhuizen PC (2005) Phylogeography of the calanoid copepods Calanus helgolandicus and C. euxinus suggests Pleistocene divergences between Atlantic, Mediterranean, and Black Sea populations. Mar Biol 147:1353-1365

R Core Team (2018) R: A language and environment for statistical computing. Vienna, Austria. http://www.r-project.org/

Raupach MJ, Barco A, Steinke D, Beermann J, Laakmann S, Mohrbeck I, Neumann H, Kihara TC, Pointner K, Radulovici A, Segelken-Voigt A, Wesse C, Knebelsberger T (2015) The application of DNA barcodes for the identification of marine crustaceans from the North Sea and adjacent regions. PLoS One 10:e0139421

Sammarco PW, Brazeau DA, McKoin M, Strychar KB (2017) Tubastraea micranthus , comments on the population genetics of a new invasive coral in the western Atlantic and a possible secondary invasion. J Exp Mar Bio Ecol 490:56-63

Sammarco PW, Brazeau DA, Sinclair J (2012) Genetic connectivity in scleractinian corals across the northern Gulf of Mexico: Oil/gas platforms, and relationship to the Flower Garden Banks. PLoS One 7:e30144

Sas H, Kamermans P, Have T van der, CHristianen M, Coolen J, Lengkeek W, Didderen K, Driessen F, Bergsma J, Gool A van, Pool J van der, Weide B van der (2018) Shellfish bed restoration pilots 

Voordelta, The Netherlands, Annual report 2017. Sascon, Bureau Waardenburg, Wageningen Marine Research, 46 p.

Sethuraman A, Hey J (2016) IMa2p - parallel MCMC and inference of ancient demography under the Isolation with migration (IM) model. Mol Ecol Resour 16:206-215

Sheader M (1981) Development and growth in laboratory-maintained and field populations of Parathemisto gaudichaudi (Hyperiidea: Amphipoda). J Mar Biol Assoc United Kingdom 61:769787

Sheader M, Chia FS (1970) Development, fecundity and brooding behaviour of the amphipod, Marinogammarus obtusatus. J Mar Biol Assoc United Kingdom 50:1079-1099

Staden R, Beal KF, Bonfield JK (2000) The Staden Package, 1998. In: Bioinformatics Methods and Protocols. Humana Press, New Jersey, p 115-130

Tajima F (1989) Statistical method for testing the neutral mutation hypothesis by DNA polymorphism. Genetics 123:585-595

Wilke T, Schultheiß R, Albrecht C (2009) As time goes by: A simple fool's guide to molecular clock approaches in invertebrates. Am Malacol Bull 27:25-45

Zintzen V, Massin C, Norro A, Mallefet J (2006) Epifaunal inventory of two shipwrecks from the Belgian Continental Shelf. Hydrobiologia 555:207-219

Zintzen V, Norro A, Massin C, Mallefet J (2008a) Spatial variability of epifaunal communities from artificial habitat: Shipwrecks in the Southern Bight of the North Sea. Estuar Coast Shelf Sci 76:327-344

Zintzen V, Norro A, Massin C, Mallefet J (2008b) Temporal variation of Tubularia indivisa (Cnidaria, Tubulariidae) and associated epizoites on artificial habitat communities in the North Sea. Mar Biol 153:405-420 
Table 1. Jassa herdmani sampling locations with genetic diversity statistics in the southern North Sea; $\mathrm{N}=$ number of individuals genotyped; $\mathrm{H}=$ haplotype diversity; $\pi$ = nucleotide diversity; s.d. = standard deviation; $D=$ Tajima's $D ; F_{s}=$ Fu's $F_{s} ;$ n.a. = not applicable; none of the $D$ or $F_{s}$ values differ significantly from zero.

\begin{tabular}{|c|c|c|c|c|c|c|c|c|c|c|}
\hline Sample & Type & Date & Depth (m) & Latitude $\left({ }^{\circ} \mathrm{N}\right)$ & Longitude $\left({ }^{\circ} \mathrm{E}\right)$ & $\mathrm{N}$ & $H$ (s.d.) & $\pi$ (s.d.) & D & $\mathrm{F}_{\mathrm{s}}$ \\
\hline SP1033 & platform & $28-06-2016$ & $0-26$ & 53.402722 & 4.2013444 & 15 & $0.800(0.077)$ & 0.00605 (0.00359) & -0.767 & 1.053 \\
\hline SP0654 & platform & $20-10-2015$ & $0-30$ & 54.852894 & 4.6949389 & 38 & $0.741(0.055)$ & $0.00778(0.00428)$ & 0.640 & 2.813 \\
\hline ST0725 & turbine & 23-09-2015 & 4 & 55.195 & 7.1583333 & 33 & $0.856(0.040)$ & $0.00550(0.00318)$ & 0.163 & -1.228 \\
\hline ST0729 & turbine & $29-06-2015$ & 5 & 53.69 & 6.498 & 41 & $0.746(0.061)$ & $0.00639(0.00360)$ & -1.043 & -2.082 \\
\hline SW0566 & wreck & $11-06-2015$ & 30 & 52.766283 & 4.2129833 & 15 & $0.562(0.095)$ & $0.00428(0.00268)$ & 0.537 & 3.888 \\
\hline SW0569 & wreck & $11-06-2015$ & 30 & 53.121 & 4.2071667 & 17 & $0.221(0.121)$ & $0.00168(0.00129)$ & -0.820 & 3.034 \\
\hline SW0932 & wreck & $11-06-2016$ & 34 & 52.494966 & 3.282189 & 36 & $0.732(0.045)$ & $0.00390(0.00238)$ & 1.472 & 0.668 \\
\hline SW0933 & wreck & 08-06-2016 & 30 & 51.979767 & 3.5012 & 24 & $0.714(0.067)$ & $0.00384(0.00239)$ & 0.574 & 1.713 \\
\hline SW0934 & wreck & $15-06-2016$ & 35 & 52.246933 & 3.1502833 & 40 & $0.672(0.051)$ & $0.00331(0.00208)$ & -0.705 & 1.109 \\
\hline SW0935 & wreck & $14-06-2016$ & 32 & 52.789183 & 3.0528333 & 43 & $0.797(0.042)$ & $0.00431(0.00257)$ & -0.576 & -2.327 \\
\hline SW0936 & wreck & 17-06-2016 & 46 & 51.773183 & 2.8429667 & 41 & $0.795(0.038)$ & $0.00368(0.00226)$ & 0.106 & 0.688 \\
\hline SW0937 & wreck & 17-06-2016 & 30 & 51.83 & 2.8183333 & 36 & $0.675(0.081)$ & $0.00309(0.00197)$ & 0.153 & -1.720 \\
\hline SW0939 & wreck & $16-06-2016$ & 42 & 52.0801 & 2.6723833 & 36 & $0.821(0.036)$ & $0.00428(0.00257)$ & 0.884 & -0.519 \\
\hline SW0940 & wreck & $12-06-2016$ & 32 & 52.507883 & 3.3196667 & 45 & $0.778(0.043)$ & $0.00349(0.00216)$ & 0.327 & -0.106 \\
\hline SW0941 & wreck & $10-06-2016$ & 28 & 52.436683 & 3.7328333 & 17 & $0.868(0.068)$ & $0.00483(0.00294)$ & 0.271 & -2.102 \\
\hline SW0942 & wreck & $11-06-2016$ & 40 & 52.606833 & 3.0845167 & 22 & $0.736(0.060)$ & $0.00361(0.00228)$ & 0.761 & 1.357 \\
\hline SW0943 & wreck & $15-06-2016$ & 32 & 52.2454 & 3.0425833 & 15 & $0.867(0.057)$ & $0.00423(0.00265)$ & 1.051 & -0.911 \\
\hline Godewind & turbine & 07-10-2016 & 0 & 53.98833 & 7.063333 & 1 & n.a. & n.a. & n.a. & n.a. \\
\hline SP1009 & platform & 24-06-2016 & $4-13$ & 53.39321 & 4.201086 & 5 & n.a. & n.a. & n.a. & n.a. \\
\hline BARD1 & turbine & $27-05-2016$ & 0 & 54.31048 & 5.939418 & 4 & n.a. & n.a. & n.a. & n.a. \\
\hline SP0225 & platform & $12-10-2014$ & $0-20$ & 53.4 & 4.2 & 4 & n.a. & n.a. & n.a. & n.a. \\
\hline ST0727 & turbine & $30-06-2015$ & 4 & 53.69767 & 6.512167 & 1 & n.a. & n.a. & n.a. & n.a. \\
\hline
\end{tabular}


Table 2. Analyses of molecular variance (AMOVA) for Jassa herdmani partial cytochrome-c-oxidase 1 (COI) sequences.

\begin{tabular}{|c|c|c|c|c|c|}
\hline \multicolumn{6}{|l|}{ A. One-level AMOVA } \\
\hline Source of variation & d.f. & Sum of squares & Variance components & Percentage of variation & Fixation index \\
\hline Among samples & 16 & 155.323 & 0.27524 & 15.92 & \\
\hline Within samples & 497 & 722.402 & 1.45353 & 84.08 & \\
\hline Total & 513 & 877.726 & 1.72877 & & $\Phi_{\text {ST }}=0.159(p<0.00001)$ \\
\hline \multicolumn{6}{|c|}{ B. Two-level AMOVA: ship wrecks versus platforms and turbines } \\
\hline Source of variation & d.f. & Sum of squares & Variance components & Percentage of variation & Fixation index \\
\hline Between structures & 1 & 30.521 & 0.11001 & 6.13 & $\Phi_{C T}=0.0613(p=0.0144)$ \\
\hline Among samples within structures & 15 & 124.803 & 0.23140 & 12.89 & $\Phi_{s c}=0.137(p<0.00001)$ \\
\hline Within samples & 497 & 722.402 & 1.45353 & 80.98 & \\
\hline Total & 513 & 877.726 & 1.79493 & & $\Phi_{\text {ST }}=0.190(p<0.00001)$ \\
\hline \multicolumn{6}{|c|}{ C. Two-level AMOVA: 2015 versus 2016} \\
\hline Source of variation & d.f. & Sum of squares & Variance components & Percentage of variation & Fixation index \\
\hline Between years & 1 & 24.208 & 0.07036 & 3.98 & $\Phi_{\text {CT }}=0.03978(p=0.0315)$ \\
\hline Among samples within years & 15 & 131.116 & 0.24484 & 13.84 & $\Phi_{s c}=0.144(p<0.00001)$ \\
\hline Within samples & 497 & 722.402 & 1.45353 & 82.18 & \\
\hline Total & 513 & 877.726 & 1.76873 & & $\Phi_{\mathrm{ST}}=0.178(p<0.00001)$ \\
\hline
\end{tabular}


Table 3. Pairwise comparison of population genetic differentiation $\left(\Phi_{\text {ST }}\right)$ for Jassa herdmani among 17 locations in the southern North Sea. Values in bold are significantly different from zero after Bonferroni correction.

\begin{tabular}{|c|c|c|c|c|c|c|c|c|c|c|c|c|c|c|c|c|}
\hline & SP1033 & SP0654 & ST0725 & ST0729 & SW0566 & SW0569 & SW0932 & SW0933 & SW0934 & SW0935 & SW0936 & SW0937 & SW0939 & SW0940 & SW0941 & SW0942 \\
\hline SP1033 & - & & & & & & & & & & & & & & & \\
\hline SP0654 & 0.053 & - & & & & & & & & & & & & & & \\
\hline ST0725 & 0.021 & 0.124 & - & & & & & & & & & & & & & \\
\hline ST0729 & 0.078 & 0.044 & 0.113 & - & & & & & & & & & & & & \\
\hline SW0566 & 0.152 & 0.095 & 0.206 & -0.015 & - & & & & & & & & & & & \\
\hline SW0569 & 0.206 & 0.137 & 0.303 & 0.074 & 0.077 & - & & & & & & & & & & \\
\hline SW0932 & 0.338 & 0.222 & 0.333 & 0.091 & 0.055 & 0.293 & - & & & & & & & & & \\
\hline SW0933 & 0.334 & 0.231 & 0.310 & 0.142 & 0.187 & 0.411 & 0.089 & - & & & & & & & & \\
\hline SW0934 & 0.246 & 0.150 & 0.238 & 0.061 & 0.100 & 0.267 & 0.231 & 0.304 & - & & & & & & & \\
\hline SW0935 & 0.184 & 0.143 & 0.127 & 0.083 & 0.158 & 0.326 & 0.253 & 0.307 & 0.097 & - & & & & & & \\
\hline SW0936 & 0.191 & 0.140 & 0.150 & 0.073 & 0.157 & 0.317 & 0.263 & 0.295 & 0.043 & 0.015 & - & & & & & \\
\hline SW0937 & 0.238 & 0.141 & 0.220 & 0.075 & 0.150 & 0.318 & 0.267 & 0.305 & -0.008 & 0.083 & 0.016 & - & & & & \\
\hline SW0939 & 0.042 & 0.113 & 0.048 & 0.082 & 0.152 & 0.271 & 0.304 & 0.306 & 0.127 & 0.097 & 0.085 & 0.110 & - & & & \\
\hline SW0940 & 0.347 & 0.207 & 0.320 & 0.103 & 0.123 & 0.343 & 0.189 & 0.334 & 0.071 & 0.117 & 0.133 & 0.121 & 0.247 & - & & \\
\hline SW0941 & 0.272 & 0.165 & 0.249 & 0.073 & 0.100 & 0.359 & 0.147 & 0.242 & 0.063 & 0.070 & 0.085 & 0.094 & 0.187 & 0.006 & - & \\
\hline SW0942 & 0.282 & 0.155 & 0.283 & 0.053 & 0.048 & 0.278 & 0.147 & 0.311 & 0.054 & 0.110 & 0.124 & 0.114 & 0.216 & -0.019 & 0.010 & - \\
\hline SW0943 & 0.138 & 0.092 & 0.125 & 0.018 & 0.074 & 0.289 & 0.127 & 0.104 & 0.095 & 0.062 & 0.040 & 0.069 & 0.088 & 0.177 & 0.100 & 0.148 \\
\hline
\end{tabular}


Table 4. Estimated divergence times and other parameters for Jassa herdmani based on coalescent isolation-with-migration simulations, carried out for three sample pairs that had among the highest pairwise $\Phi_{\text {ST }}$ values in order to gauge what the oldest splitting times among the studied locations may have been.

\begin{tabular}{|c|c|c|c|c|c|c|c|}
\hline Sample 0 & Sample 1 & $\begin{array}{r}\text { Divergence time } \\
\text { (years) }\end{array}$ & $\begin{array}{r}\text { Migration rate } 0>1 \\
(2 \mathrm{Nm})\end{array}$ & $\begin{array}{r}\text { Migration } 1>0 \\
(2 \mathrm{Nm})\end{array}$ & Population size 0 & Population size 1 & $\begin{array}{r}\text { Ancestral } \\
\text { population size }\end{array}$ \\
\hline SW0569 & SW0933 & 11,080 & 0.31 & 0.058 & 5,120 & 270 & 145,778 \\
\hline SW0933 & SW0940 & 5,303 & 0.19 & 0.18 & 19,132 & 6,198 & 161,946 \\
\hline SP1033 & SW0932 & 3,578 & 0.61 & 0.062 & 20,748 & 8,353 & 206,676 \\
\hline
\end{tabular}




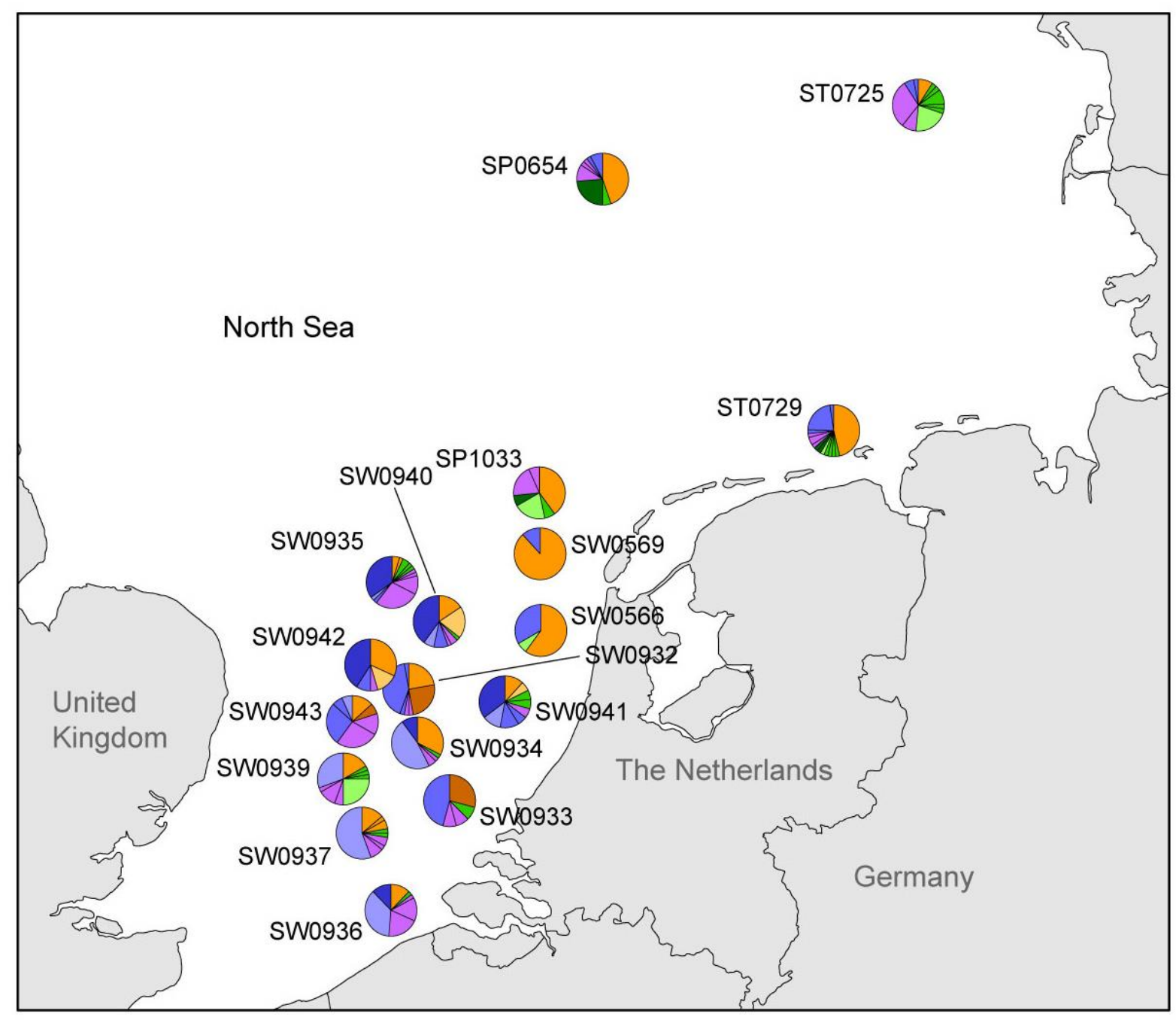

Figure 1. Distribution of sampling locations showing spatial distribution of COI haplotypes across the southern North Sea for Jassa herdmani. Note that only samples of sufficient size ( $\mathrm{N}>=15$ ) are shown. Haplotype colours correspond to those in Figure 2. 


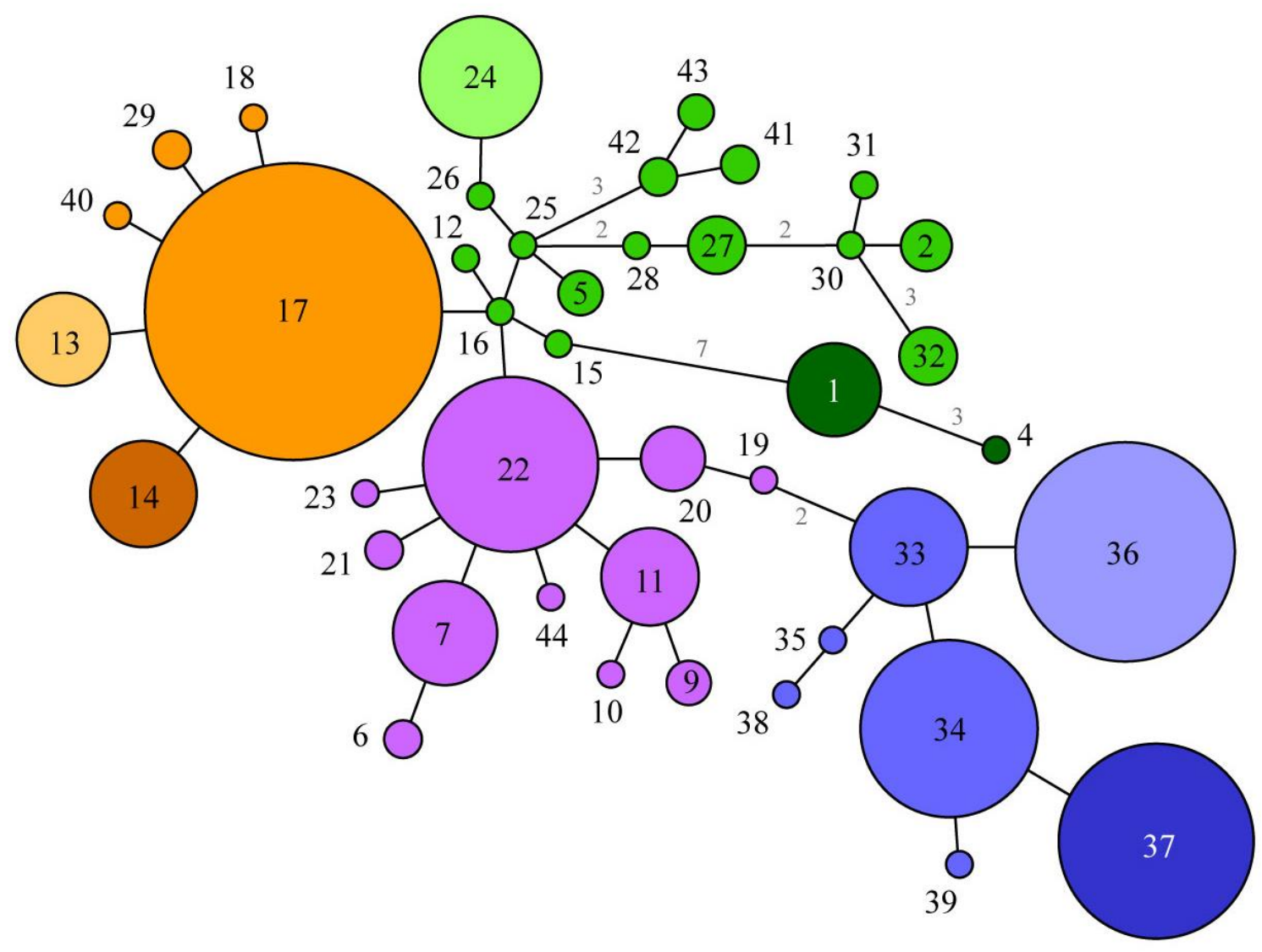

Figure 2. Haplotype minimum spanning network among partial cytochrome c oxidase I (COI) sequences for Jassa herdmani. Circle area is proportional to frequency of occurrence. Numbers in black or white denote haplotype identity; branch lengths are one base pair substitution unless otherwise indicated (in grey numbers). Haplotype colours correspond to those in Figure 1. Colours were chosen to reflect relatedness in the haplotype network. Note that only the 42 haplotypes from samples of sufficient size $(\mathrm{N}>=15)$ are included here, which means that numbers 3 and 8 are not shown. 


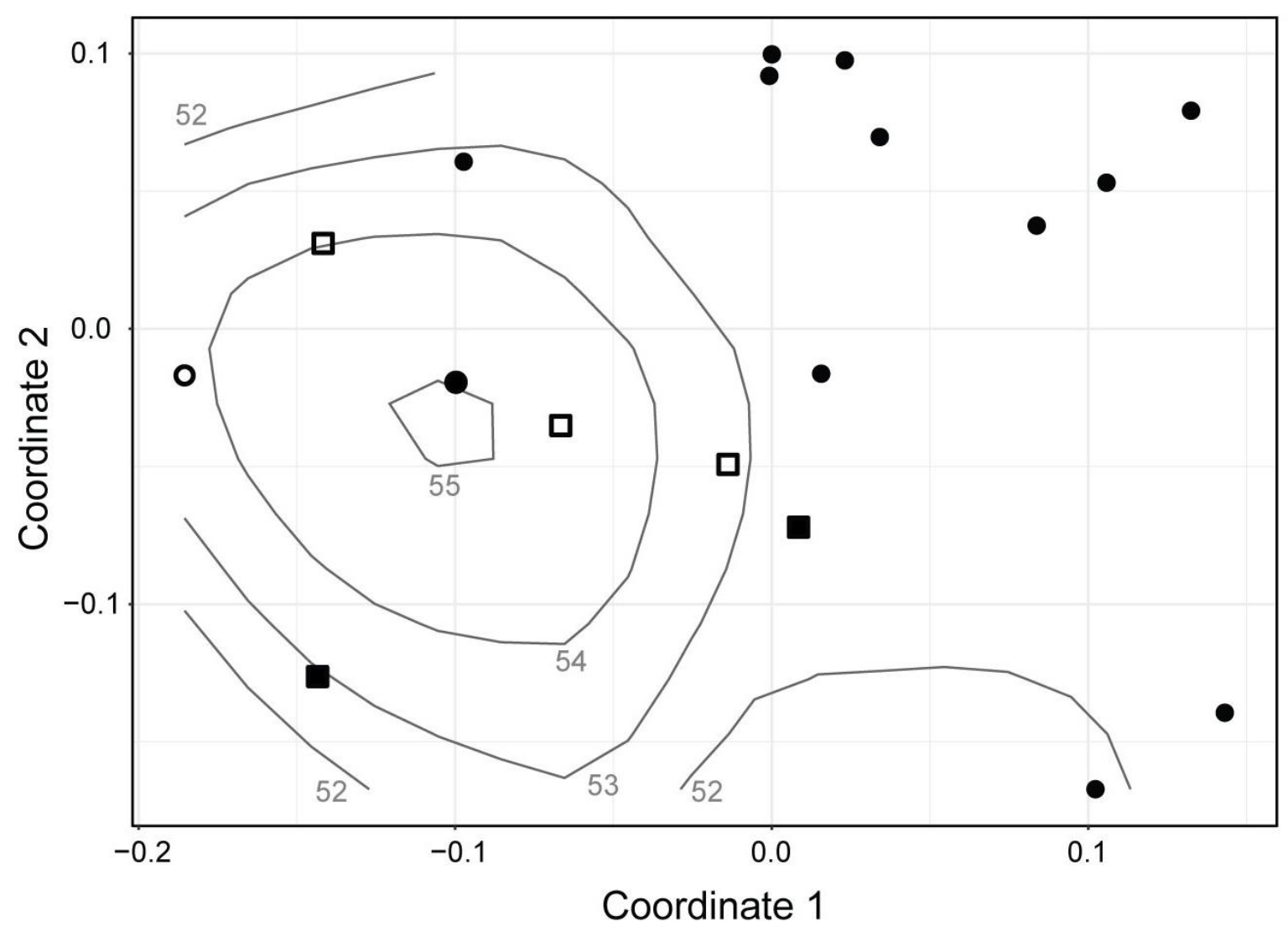

Figure 3. Multidimensional scaling plot (MDS) for Jassa herdmani samples consisting of partial cytochrome-c-oxidase 1 sequences collected at 17 offshore southern North Sea locations. Grey lines with grey numbers are latitudinal isolines; open symbols are platforms and turbines and closed symbols are ship wrecks; square symbols are samples taken in 2015 and round symbols in 2016. 


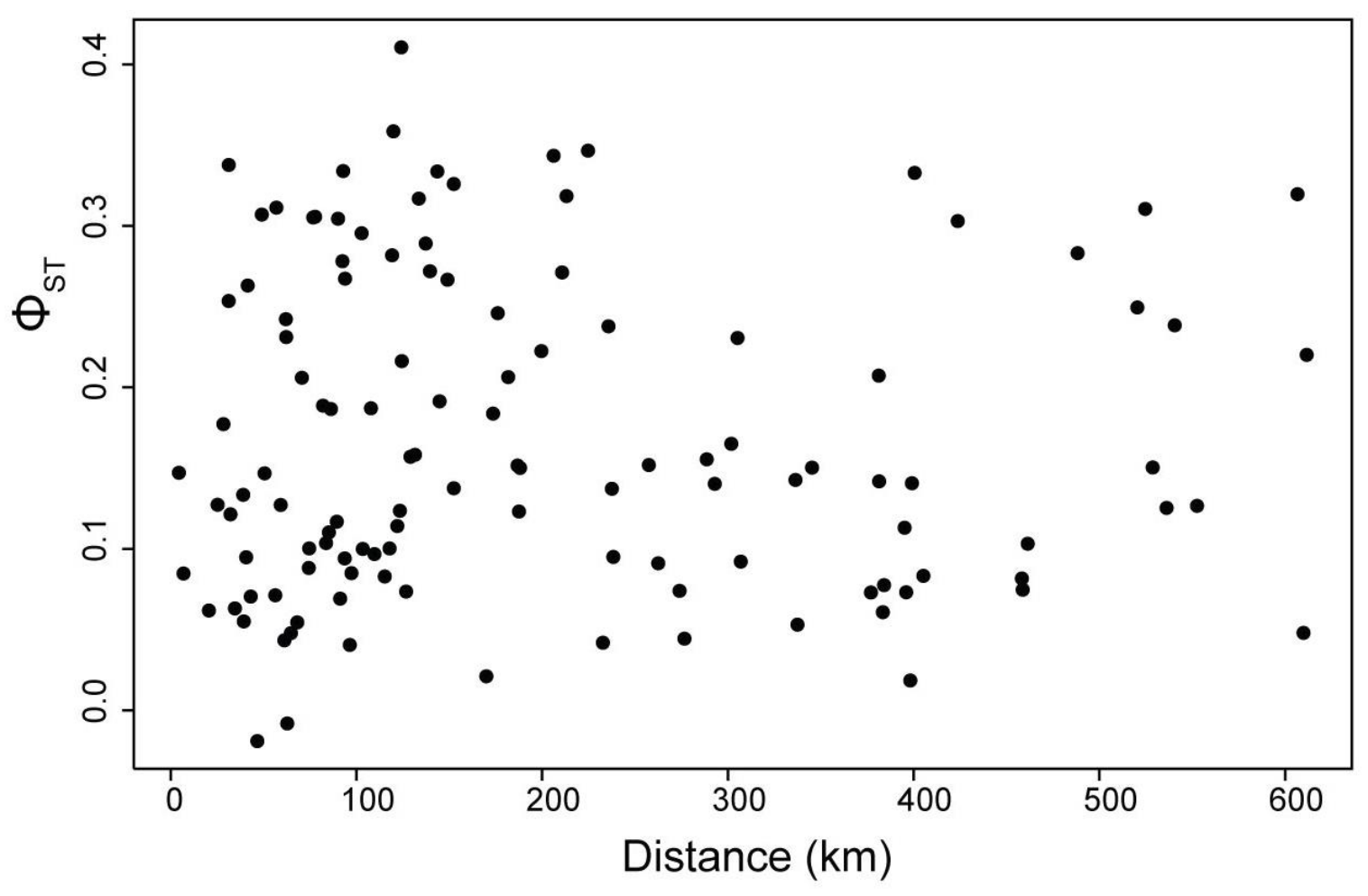

Figure 4. Graph showing absence of isolation-by-distance among sampled Jassa herdmani locations in the southern North Sea region. $\Phi_{S T}=$ pairwise level of population differentiation . 
The following supplement accompanies the article

Low genetic connectivity in a fouling amphipod among man-made structures in the southern North Sea

Pieternella C. Luttikhuizen*, Jan Beermann, Richard P. M. A. Crooijmans, Robbert G. Jak, Joop W. P. Coolen *Corresponding author: pieternella.luttikhuizen@nioz.n

\begin{tabular}{|c|c|c|c|c|c|c|c|c|c|c|c|c|c|c|c|c|c|}
\hline haplotype L10A & SP0654 & ST0725 & ST0729 & SW056 & 5 SW0569 & sW0932 & sW0933 & SW0934 & SW0935 & SW0936 & 6 SW0937 & $7 \quad$ SW093s & 9 sw094C & sW0941 & 1 sW0942 & & SW0943 \\
\hline 1 & 1 & 9 & 0 & 1 & 0 & 0 & 0 & 0 & 0 & 0 & 0 & 0 & 0 & 0 & 0 & 0 & 0 \\
\hline 2 & 0 & 2 & 1 & 1 & 0 & 0 & 0 & 0 & 0 & 0 & 0 & 0 & 0 & 0 & 0 & 0 & 0 \\
\hline 4 & 0 & 0 & 0 & 1 & 0 & 0 & 0 & 0 & 0 & 0 & 0 & 0 & 0 & 0 & 0 & 0 & 0 \\
\hline 5 & 0 & 0 & 1 & 0 & 0 & 0 & 0 & 0 & 0 & 2 & 0 & 0 & 0 & 0 & 0 & 0 & 0 \\
\hline 7 & 3 & 4 & 0 & 1 & 0 & 0 & 0 & 0 & 1 & 1 & 1 & 2 & 2 & 0 & 0 & 0 & 2 \\
\hline 9 & 0 & 0 & 0 & 0 & 0 & 0 & 0 & 0 & 0 & 0 & 0 & 0 & 0 & 2 & 0 & 1 & 0 \\
\hline 10 & 0 & 0 & 0 & 0 & 0 & 0 & 1 & 0 & 0 & 0 & 0 & 0 & 0 & 0 & 0 & 0 & 0 \\
\hline 11 & 1 & 0 & 3 & 2 & 0 & 0 & 0 & 0 & 0 & 1 & 6 & 1 & 0 & 0 & 0 & 0 & 0 \\
\hline 15 & 0 & 0 & 0 & 0 & 0 & 0 & 0 & 0 & 0 & 0 & 0 & 0 & 1 & 0 & 0 & 0 & 0 \\
\hline 16 & 0 & 0 & 0 & 0 & 0 & 0 & 0 & 0 & 0 & 0 & 0 & 1 & 0 & 0 & 0 & 0 & 0 \\
\hline 17 & 6 & 17 & 3 & 19 & 9 & 15 & 8 & 0 & 13 & 2 & 5 & 5 & 6 & 7 & 2 & 7 & 2 \\
\hline 18 & 0 & 0 & 0 & 0 & 0 & 0 & 0 & 0 & 0 & 0 & 0 & 1 & 0 & 0 & 0 & 0 & 0 \\
\hline 19 & 0 & 0 & 0 & 0 & 0 & 0 & 1 & 0 & 0 & 0 & 0 & 0 & 0 & 0 & 0 & 0 & 0 \\
\hline 20 & 0 & 0 & 0 & 0 & 0 & 0 & 0 & 0 & 0 & 5 & 0 & 0 & 0 & 1 & 0 & 0 & 0 \\
\hline 21 & 0 & 0 & 0 & 0 & 0 & 0 & 0 & 2 & 0 & 0 & 0 & 0 & 0 & 0 & 0 & 0 & 0 \\
\hline 27 & 0 & 0 & 3 & 1 & 0 & 0 & 0 & 0 & 0 & 1 & 0 & 0 & 0 & 0 & 0 & 0 & 0 \\
\hline 28 & 0 & 0 & 0 & 0 & 0 & 0 & 0 & 0 & 0 & 0 & 0 & 0 & 0 & 1 & 0 & 0 & 0 \\
\hline 29 & 0 & 0 & 0 & 0 & 0 & 0 & 0 & 0 & 0 & 0 & 0 & 2 & 0 & 0 & 0 & 0 & 0 \\
\hline 30 & 0 & 0 & 0 & 1 & 0 & 0 & 0 & 0 & 0 & 0 & 0 & 0 & 0 & 0 & 0 & 0 & 0 \\
\hline 31 & 0 & 0 & 1 & 0 & 0 & 0 & 0 & 0 & 0 & 0 & 0 & 0 & 0 & 0 & 0 & 0 & 0 \\
\hline 32 & 1 & 0 & 1 & 0 & 0 & 0 & 0 & 0 & 1 & 1 & 0 & 0 & 0 & 0 & 0 & 0 & 0 \\
\hline 33 & 0 & 1 & 2 & 1 & 0 & 0 & 1 & 11 & 0 & 0 & 0 & 0 & 0 & 0 & 1 & 0 & 4 \\
\hline 34 & 0 & 3 & 1 & 9 & 5 & 2 & 15 & 0 & 0 & 0 & 0 & 0 & 0 & 4 & 2 & 2 & 1 \\
\hline 35 & 0 & 0 & 0 & 1 & 0 & 0 & 0 & 0 & 0 & 0 & 0 & 0 & 0 & 0 & 0 & 0 & 0 \\
\hline 36 & 0 & 0 & 0 & 0 & 0 & 0 & 0 & 0 & 19 & 1 & 15 & 20 & 11 & 3 & 2 & 0 & 1 \\
\hline 37 & 0 & 0 & 0 & 0 & 0 & 0 & 0 & 0 & 4 & 15 & 5 & 0 & 0 & 18 & 6 & 9 & 0 \\
\hline 38 & 0 & 0 & 0 & 0 & 0 & 0 & 0 & 0 & 0 & 1 & 0 & 0 & 0 & 0 & 0 & 0 & 0 \\
\hline 39 & 0 & 0 & 0 & 0 & 0 & 0 & 1 & 0 & 0 & 0 & 0 & 0 & 0 & 0 & 0 & 0 & 0 \\
\hline 40 & 0 & 0 & 0 & 0 & 0 & 0 & 0 & 0 & 0 & 1 & 0 & 0 & 0 & 0 & 0 & 0 & 0 \\
\hline 41 & 0 & 0 & 0 & 0 & 0 & 0 & 0 & 2 & 0 & 0 & 0 & 0 & 0 & 0 & 0 & 0 & 0 \\
\hline
\end{tabular}

